\title{
Photolabile Protecting Groups for Nucleosides: Mechanistic Studies of the 2-(2-Nitrophenyl)ethyl Group
}

\author{
by Stefan Walbert, Wolfgang Pfleiderer, and Ulrich E. Steiner* \\ Fachbereich Chemie der Universität Konstanz, D-78457 Konstanz \\ Dedicated with best wishes to Prof. Edgar Heilbronner on the occasion of his 80th birthday
}

\begin{abstract}
The photochemistry of several 2-(2-nitrophenyl)ethyl-caged compounds including caged thymidine nucleosides was studied by nanosecond laser flash photolysis and stationary illumination experiments with quantitative HPLC analysis for quantum yields and product distribution. Effects of solvent basicity and acidity were investigated by varying the $\mathrm{H}_{2} \mathrm{O}$ content and $\mathrm{HCl}$ concentration, respectively, in $\mathrm{MeCN} / \mathrm{H}_{2} \mathrm{O}$ mixtures. For all compounds 1-7 investigated, intramolecular $\mathrm{H}$ abstraction by the nitro group from the exocyclic $\alpha$-position with respect to the aryl moiety was found to be the primary process. The protolytic dissociation equilibrium of the resulting aci-nitro compound was kinetically characterized in the $0.1-10 \mu$ s time region. In general, two reaction channels compete for the aci-nitro compound and its anion: $\beta$-elimination of the caged compound occurs from the anion, while from the undissociated aci-nitro compound, a nitrosobenzene derivative is formed with no release of the caged compound. The yield ratio of these two reaction channels can be controlled through shifts in the protolytic dissociation equilibrium of the aci-nitro compound. In solutions with either low basicity $\left(\mathrm{H}_{2} \mathrm{O}\right.$-free $\mathrm{MeCN}$ ) or high acidity (higher concentration of $\mathrm{HCl}$ in $\mathrm{H}_{2} \mathrm{O} / \mathrm{MeCN}$ ), two as yet unidentified products are formed, each one specifically for one of the mentioned conditions.
\end{abstract}

Introduction. - Photolabile protecting groups play an important role in synthetic organic chemistry [1], for caging of biologically active molecules [2], and for lightdirected, combinatorial solid-phase syntheses of biopolymers [3]. A particularly attractive application is the generation of so-called high-density DNA chips [4][5] which are needed in various types to perform the sequencing by hybridisation $(\mathrm{SBH})$ method for oligonucleotide and gene sequencing [6]. The $o$-nitrobenzyl $(o \mathrm{NB})$ type of protecting groups has been commonly used since 1901 when the photoreaction was discovered [7], and its reaction mechanism has been investigated in detail [8]. So far, the [( $\alpha$-methyl-2-nitropiperonyl)oxy]carbonyl ([1-(6-nitro-1,3-benzodioxol-5-yl)ethoxy]carbonyl; MeNPOC) group has been the preferred choice in DNA-chip production [4].

The photochemical cleavage mechanism of the (o-nitrobenzyl)oxy function is triggered by the abstraction of a benzylic $\mathrm{H}$-atom by the excited nitro group [9]. Recently, a new type of photolabile protecting group was developed on the basis of the [2-(2-nitrophenyl)ethoxy]carbonyl functionality [10][11] which is cleaved by a lightinduced $\beta$-elimination process with formation of $o$-nitrostyrene, $\mathrm{CO}_{2}$, and the corresponding alcohol. It was suggested [10] that, in analogy to the $o$-nitrobenzyl groups, the cleavage of the [2-(2-nitrophenyl)ethoxy]carbonyl moiety, too, should start with the formation of an aci-nitro intermediate, through $\mathrm{H}$ abstraction by the nitro group at the exocyclic $\alpha$-position with respect to the aryl moiety. Based on results from laser flash photolysis and quantitative stationary irradiation experiments, the present

Konstanzer Online-Publikations-System (KOPS)

URL: http://www.ub.uni-konstanz.de/kops/volltexte/2008/4742/

URN: http://nbn-resolving.de/urn:nbn:de:bsz:352-opus-47420 
paper presents evidence of the suggested reaction mechanism and provides further insight into the cleavage mechanism of the new type of photolabile protecting groups.

Results. - Laser Flash Photolysis. Laser flash photolysis studies on time scales from nanoseconds to seconds were carried out with the ring- and chain-substituted derivatives 1-7 of (2-nitrophenyl)ethane (oNPE) (Fig. 1) in $\mathrm{MeOH} / \mathrm{H}_{2} \mathrm{O}, \mathrm{MeCN}$, and $\mathrm{MeCN} / \mathrm{H}_{2} \mathrm{O}$. In all cases, the typical spectra of the aci-nitro compounds with their characteristic maxima around $400 \mathrm{~nm}$ [12] were observed. As examples, in Fig. 2, we present transient spectra for 2-(2-chloro-6-nitrophenyl)ethyl acetate (1) and 2-(2nitrophenyl)propyl acetate (2) in $\mathrm{MeCN} / \mathrm{H}_{2} \mathrm{O} 1: 1(v / v)$.

It is of interest to note that, while the differences in the extinction coefficients of the two compounds 1 and 2 at the laser wavelength of $355 \mathrm{~nm}\left(\varepsilon=340\right.$ and $400 \mathrm{M}^{-1} \mathrm{~cm}^{-1}$ for $\mathbf{1}$ and $\mathbf{2}$, resp.) are only minor and the same laser intensity was applied, the initial signal amplitudes after the laser flash differ by a factor of $c a$. 4 between the two compounds. This indicates that the primary reaction for the $\alpha$-methylated compound ( $\alpha$ denotes the exocyclic position with respect to the aryl moiety) is much more efficient. During the first microseconds after the laser flash, the initial transient absorption band undergoes a slight bathochromic shift that is indicative of protolytic dissociation of the aci-nitro compound, i.e., appearance of the corresponding anion. The extent and rate of this dissociation process can be modified by the nature of the solvent and the acidity of the solution. This is demonstrated in Fig. 3 where kinetic traces are shown for a variation of<smiles>[R7]CC([R])c1c([N+](=O)[O-])ccc([R7])c1[R]</smiles>

a) For synthesis, $c f$. [10].

\begin{tabular}{l|cccc} 
& $\mathbf{R}^{\mathbf{1}}$ & $\mathbf{R}^{\mathbf{2}}$ & $\mathbf{R}^{\mathbf{3}}$ & $\mathbf{R}^{\mathbf{4}}$ \\
\hline $\mathbf{1}$ & $\mathrm{H}$ & $\mathrm{Cl}$ & $\mathrm{H}$ & $\mathrm{Ac}$ \\
$\mathbf{2}$ & $\mathrm{H}$ & $\mathrm{H}$ & $\mathrm{Me}$ & $\mathrm{Ac}$ \\
$\mathbf{3}$ & $\mathrm{Br}$ & $\mathrm{H}$ & $\mathrm{Me}$ & COOMe \\
$\mathbf{4}^{\mathbf{a}}$ & $\mathrm{H}$ & $\mathrm{Cl}$ & $\mathrm{H}$ & $\mathrm{CO}-5^{\prime}-O$-thymidine \\
$\mathbf{5}^{\text {a) }}$ & $\mathrm{H}$ & $\mathrm{H}$ & $\mathrm{Me}$ & CO-5'- $O$-thymidine \\
$\mathbf{6}$ & $\mathrm{H}$ & $\mathrm{H}$ & $\mathrm{Me}$ & COOMe \\
$\mathbf{7}^{\mathbf{a}}$ & $\mathrm{H}$ & $\mathrm{H}$ & $\mathrm{Me}$ & $\mathrm{H}$
\end{tabular}

Fig. 1. 2-(2-Nitrophenyl)ethyl derivatives 1-7 investigated in this work
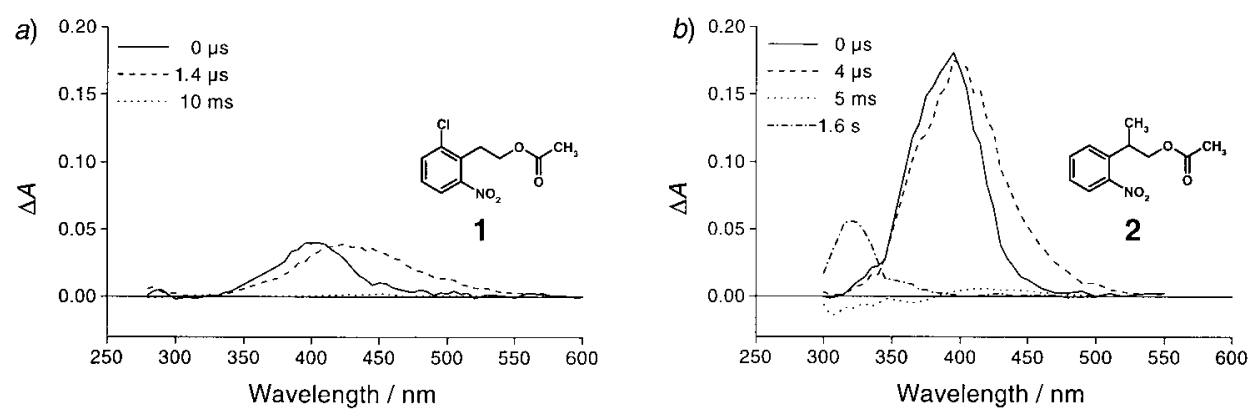

Fig. 2. Transient absorption spectra observed at various delay times after laser flash photolysis of $0.5 \mathrm{mM}$ solutions of a) $\mathbf{1}$ and b) 2 in $\mathrm{MeCN} / \mathrm{H}_{2} \mathrm{O} 1: 1(\mathrm{v} / \mathrm{v})$ 
the $\mathrm{MeCN} / \mathrm{H}_{2} \mathrm{O}$ ratio (Fig. 3,a) and for varying concentrations of $\mathrm{HCl}$ (Fig. 3,b), respectively. The sample compound used in this study was 2-(5-bromo-2-nitrophenyl)propyl methyl carbonate (3), which was synthesized in several steps from $\mathrm{N}$-(3ethylphenyl)acetamide (see Exper. Part).
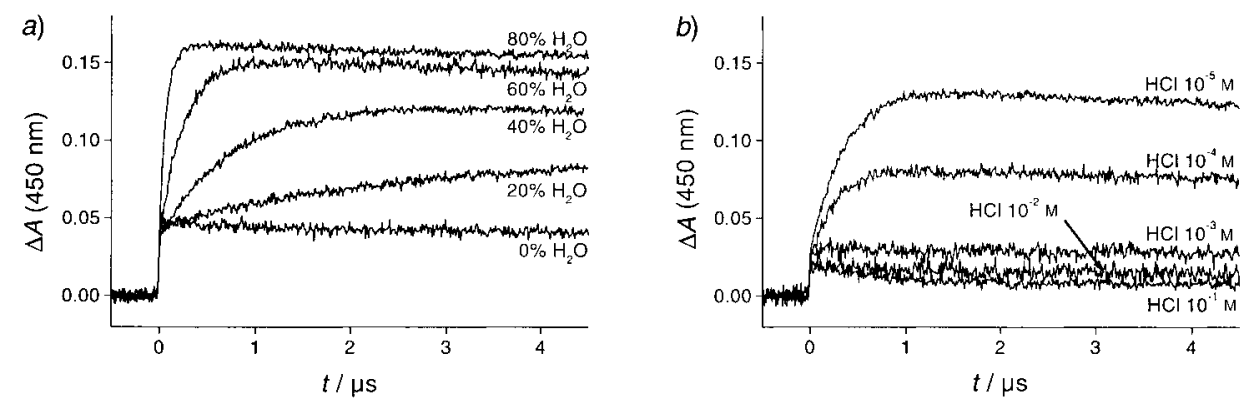

Fig. 3. Kinetic traces of transient absorption observed at $450 \mathrm{~nm}$ upon flash photolysis of compound 3: a) in $\mathrm{MeCN} / \mathrm{H}_{2} \mathrm{O}$ mixtures with variable mixing ratios and $\left.\mathrm{b}\right)$ in $\mathrm{MeCN} / \mathrm{H}_{2} \mathrm{O}$ 1:1 ( $\left.\mathrm{v} / \mathrm{v}\right)$ with various concentrations of $\mathrm{HCl}$

At $450 \mathrm{~nm}$ the absorbance of the anion generated from 3 greatly exceeds the absorbance of the aci-nitro form. Thus the rise of the signal intensity indicates the formation of the aci-nitro anion.

As can be seen in Fig. 3, $a$ for $\mathbf{3}$, the appearing rate and the amplitude of the anion absorption increase with increasing content of $\mathrm{H}_{2} \mathrm{O}$. On the other hand, in a solvent rich in $\mathrm{H}_{2} \mathrm{O}$, the rate and degree of dissociation can be reduced by lowering the $\mathrm{pH}(c f$. Fig. 3,b). The transient spectra of the aci-nitro compound and its anion completely disappear after some milliseconds. In case of compound $\mathbf{1}$, no further transient is detectable. In case of compound $\mathbf{2}$, however, a new persistent absorption band appears during fractions of seconds. The new band is very similar to what is known from investigations with the $o \mathrm{NB}$ type of protecting groups where it is assigned to the nitrosobenzaldehyde derivative. For the $o$ NPE protecting group, such a product has not been seen before. Therefore, a more detailed investigation of the photolysis products obtained under stationary illumination conditions was undertaken.

Continuous-Illumination Experiments. The quantitation of the photoreactions and the photoproducts under stationary illumination conditions is conveniently based on HPLC analysis. An example of our results with compounds $\mathbf{4}$ and $\mathbf{5}$ is shown in Fig. 4. Each peak in the chromatogram is characterized and, with the pertinent reference compound at hand, identified by its retention time and its UV spectrum.

From the concentrations of the unreacted caged compounds and of photochemically released thymidine after given illumination intervals, photochemical quantum yields of total photodecomposition $\left(\phi_{\text {tot }}\right)$ and release of the caged thymidine $\left(\phi_{\text {rel }}\right)$ were determined ( $c f$. Table 1). The caged thymidine compounds $\mathbf{4}$ and $\mathbf{5}$ differ from their analogues $\mathbf{1}$ and $\mathbf{2}$ investigated by laser flash photolysis only by the replacement of the acetate moiety by the thymidin-5'-yl carbonate function. The overall decomposition quantum yields for compound $\mathbf{5}$ carrying an $\alpha$-methyl substituent is $c a .5$ times the value of compound $\mathbf{4}$ that is unsubstituted at this $\alpha$-position (exocyclic position with respect to the aryl moiety). This observation is in good agreement with the ratio of absorption- 

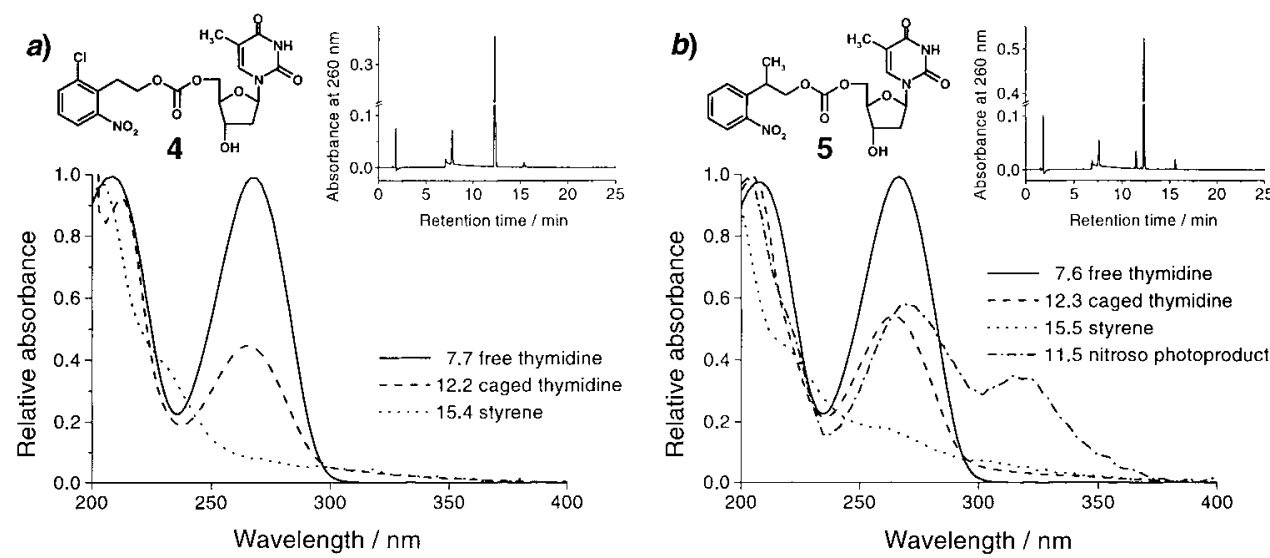

Fig. 4. HPLC Traces and UV spectra of the corresponding peaks for a) $\mathbf{4}$ and b) 5. Solutions were photolysed to ca. $20 \%$ loss of starting material in $\mathrm{MeCN} / \mathrm{H}_{2} \mathrm{O} 1: 1(\mathrm{v} / \mathrm{v})$. The peaks at $t_{\mathrm{R}} 1.8$ and $7.0 \mathrm{~min}$ are artefacts due to injection of air and passage of the gradient front across the detector.

band intensities of the primary photoproducts as seen in the laser flash photolysis of compounds $\mathbf{1}$ and $\mathbf{2}$. The similarity suggests that $i$ ) the yield of the photochemical primary product determines the final photochemical quantum yield, and that $i i$ ) the quantum yields of photoreactions of the photolabile protecting groups considered here are only little affected by the structure of the moiety to which they are attached. The latter assertion is further supported by the quantum yields observed for compounds $\mathbf{2}$, 6, and 7 having the anions $\mathrm{MeCOO}^{-}, \mathrm{MeOC}(\mathrm{O}) \mathrm{O}^{-}$, and $\mathrm{OH}^{-}$as formal leaving groups. Their quantum yields are found in a fairly narrow range of 0.39 to 0.48 which also includes the quantum yield of compound $\mathbf{5}$.

Table 1. Quantum Yields in MeCN/H $\mathrm{H}_{2} \mathrm{O} 1: 1(\mathrm{v} / \mathrm{v})$ under Stationary Illumination at 366/355 nm

\begin{tabular}{llllll}
\hline & $\mathbf{4}$ & $\mathbf{5}$ & $\mathbf{6}$ & $\mathbf{2}$ & $\mathbf{7}$ \\
\hline$\phi_{\text {tot }}$ & 0.075 & 0.40 & 0.42 & 0.48 & 0.39 \\
$\left.\phi_{\text {rel }}{ }^{a}\right)$ & 0.073 & 0.30 & - & - & - \\
\hline
\end{tabular}

a) Appearance of free thymidine.

With thymidine as the caged moiety in compounds $\mathbf{4}$ and $\mathbf{5}$, we also assessed the quantum yield of the appearance of free thymidine. For $\mathbf{4}$, this quantum yield is practically identical to the overall quantum yield $\phi_{\text {tot }}$ of photodecomposition of the starting material, and no other peaks than for thymidine and the nitrostyrene appear in the chromatogram. This means that there are no side reactions. On the other hand, for 5, the quantum yield of free thymidine is clearly lower than for the overall photoreaction. Furthermore, the chromatogram exhibits a new peak at $t_{\mathrm{R}} 11.5 \mathrm{~min}$ which, from its UV spectrum, can be assigned to a nitrosobenzene derivative. This observation meets with our finding of a nitroso-product band in the laser flash photolysis of compound $\mathbf{2}$ carrying the same protecting group as $\mathbf{5}$. Corresponding byproducts are formed for all caged substances carrying the 2-(2-nitrophenyl)propyl moiety such as $\mathbf{2 ,} \mathbf{6}$, and $\mathbf{7}$ included in Table 1 . In case of compound $\mathbf{7}$, with $\mathrm{OH}^{-}$as the 


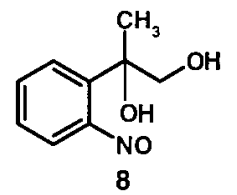

formal leaving group, nitroso-product formation is the only observed reaction path. Here no styrene, the indicator of the $\beta$-elimination pathway, is found at all.

To support this UV-spectroscopic evidence for nitroso-product formation, a larger scale photolysis of $\mathbf{7}$ was carried out, and the photoproduct $\mathbf{8}$ was isolated by column chromatography and identified by ${ }^{1} \mathrm{H}-\mathrm{NMR}$ spectroscopy (see Exper. Part). Furthermore, photolysing 7 in an NMR sample tube and measuring ${ }^{1} \mathrm{H}$-NMR spectra after certain illumination periods directly showed the conversion of $\mathbf{7}$ into the nitroso product 8 .

$\mathrm{pH}$ and Solvent Effects on Product Distribution. The consequences of $\mathrm{pH}$ and solvent variation as borne out in pronounced changes of kinetics and equilibrium position of the aci-nitro compounds' protolytic dissociation in the laser flash photolysis experiments were also explored on the level of final-product formation. Pertinent investigations were carried out with the same compound $\mathbf{3}$ that was used in the laser flash photolysis studies (cf. Fig. 3). In Table 2, the quantum yields and product-yield profiles observed after $40-50 \%$ photochemical conversion under continuous illumination at $366 \mathrm{~nm}$ are listed.

Table 2. Overall photochemical quantum yields and relative product yields for compound 3 under variation of $\mathrm{H}_{2} \mathrm{O}$ content in $\mathrm{MeCN} / \mathrm{H}_{2} \mathrm{O}$ mixtures and $\mathrm{HCl}$ concentration in $\mathrm{H}_{2} \mathrm{O} / \mathrm{MeCN} 1: 1$

\begin{tabular}{lcccccc}
\hline & $\phi_{\text {tot }}$ & $\left.\alpha^{\mathrm{a}}\right)$ & \multicolumn{2}{c}{ Yields $^{\mathrm{b}}$ ) } & & \\
\cline { 3 - 6 } & & & styrene & $\begin{array}{l}\text { nitroso } \\
\text { compound }\end{array}$ & $\mathrm{X}$ & $\mathrm{Y}$ \\
\hline $0 \% \mathrm{H}_{2} \mathrm{O}$ & 0.51 & 0 & 3.5 & 34.2 & 14.5 & 0 \\
$20 \% \mathrm{H}_{2} \mathrm{O}$ & 0.49 & 35 & 23.9 & 9.1 & 0.9 & 0 \\
$40 \% \mathrm{H}_{2} \mathrm{O}$ & 0.51 & 60 & 26.6 & 7.3 & 0 & 0 \\
$10^{-1} \mathrm{M} \mathrm{HCl}$ & 0.37 & 0 & 0 & 2.7 & 0 & 18.1 \\
$10^{-3} \mathrm{M} \mathrm{HCl}$ & 0.37 & 20 & 6.7 & 19.0 & 0 & 8.6 \\
$10^{-5} \mathrm{M} \mathrm{HCl}$ & 0.41 & 80 & 24.9 & 12.7 & 0 & 0 \\
\hline
\end{tabular}

a) Degree of protonation estimated from the laser flash photolysis experiments. ${ }^{\text {b) }}$ ) The values given represent peak integrals obtained after continuous photolysis of $0.5 \mathrm{~mm}$ solutions of $\mathbf{3}$ at $366 \mathrm{~nm}$ for $300 \mathrm{~s}$. For each product, the UV absorbance was measured at the wavelength of its optimum absorbance. Due to different $\varepsilon$ values, the data for different compounds can be compared on a qualitative basis only. For each product, however, the given data give correct ratios of the yields under different conditions. $\mathrm{X}, \mathrm{Y}=$ unknown compounds.

The following observations are of significance. $i$ ) In each of the two series (variation of $\mathrm{H}_{2} \mathrm{O}$ content or of $\mathrm{HCl}$ concentration), the total quantum yield of photodecomposition is rather invariable. ii) With a variation of the percentage of $\mathrm{H}_{2} \mathrm{O}$ in a MeCN/ $\mathrm{H}_{2} \mathrm{O}$ solvent mixture, the yield of styrene ( $\beta$-elimination pathway) and nitroso product are complementary. $\beta$-Elimination is favoured under conditions where the deprotonation of the aci-nitro compound is efficient. The reverse is true for the reaction path yielding 
the nitroso product. At low $\mathrm{H}_{2} \mathrm{O}$ content, the drop in $\beta$-elimination efficiency and the rise in nitroso product formation efficiency is accompanied by the occurrence of a new, as yet unidentified, reaction product X. iii) With an increase of acidity (concentration of $\mathrm{HCl})$ in $\mathrm{MeCN} / \mathrm{H}_{2} \mathrm{O} 1: 1(v / v)$, the $\beta$-elimination pathway is gradually suppressed and even reaches zero level at $0.1 \mathrm{M} \mathrm{HCl}$ concentration. Nitroso-product formation is first increasing with acidity but at high concentration of $\mathrm{HCl}$, it is significantly reduced while, concomitantly, another as yet unidentified product $\mathrm{Y}$ is formed.

Discussion. - The essential findings of our investigations of $o$ NPE compounds may be summarized as follows: $i$ ) The primary product in the photochemistry is the aci-nitro compound generated by $\mathrm{H}$-transfer from the exocyclic $\alpha$-position (with respect to the aryl moiety) to the nitro group. ii) The overall quantum yield of photodecomposition is proportional to the yield of primary intramolecular $\mathrm{H}$-abstraction. iii) The kinetics and equilibrium states of the protolytic dissociation of the aci-nitro forms can be observed. iv) The reaction branching between $\beta$-elimination and nitroso-product formation can be assessed. $v$ ) The product ratios can be controlled by the protolytic dissociation of the aci-nitro form. Based on these conclusions, an overall reaction mechanism as shown in the Scheme is suggested.

Upon irradiation into the first absorption band, the $\mathrm{S}_{1}\left(n \pi^{*}\right)$ of the $o \mathrm{NPE}$ chromophore is populated. It decays by intersystem crossing to the triplet state $\mathrm{T}_{1}\left(n \pi^{*}\right)$ and by internal conversion to the singlet ground state. To some extent the $\mathrm{H}-$ transfer to the nitro group may already take place in the excited singlet state, but this process is probably a main decay pathway for the triplet state. The primary product produced this way must be a triplet biradical that will rapidly relax to the $o$-quinonoid singlet ground state of the aci-nitro form, as shown in the Scheme.

In the literature, evidence has been reported both for H-transfer in the singlet and the triplet state of $n \pi^{*}$-excited $o$ NB compounds [13]. For the $o$ NPE compounds we cannot make a definite statement about the roles of $S_{1}$ and $T_{1}$ as precursors of the primary $\mathrm{H}$-transfer product in the direct photolysis process. We have evidence, however, that the same kind of primary process can be induced by triplet sensitization [14].

Since the aci-nitro compound represents an unstable tautomer of the starting compound, its reversion to the stable tautomer must be included into the reaction scheme. In general, this reaction should compete with any other reaction path of the aci-nitro compound. However, the observation ii) that the photodecomposition quantum yield is proportional to the primary yield of the aci-nitro product for compounds with or without a Me substituent at the exocyclic $\alpha$-position, suggests that this backward tautomerism cannot kinetically compete with the further reaction pathways leading to irreversible product formation. Similar conclusions have been reached for the photodecomposition of $o \mathrm{NB}$ compounds [15].

The kinetics of the protolytic dissociation of the aci-nitro compound and the establishment of a medium-dependent equilibrium is readily observable in the $0.1-$ $10 \mu \mathrm{s}$ time region. The acidity of the aci-nitro form is not high enough to allow dissociation in pure $\mathrm{MeCN}$. However, already weak bases such as $\mathrm{H}_{2} \mathrm{O}$ can act as effective proton acceptors. Thus the rate and equilibrium position of the protolytic dissociation is quite sensitive to the $\mathrm{H}_{2} \mathrm{O}$ content in $\mathrm{MeCN} / \mathrm{H}_{2} \mathrm{O}$ mixtures. On the other hand, if $\mathrm{H}_{2} \mathrm{O}$-containing solutions are acidified, suppression of the dissociation is 
Scheme

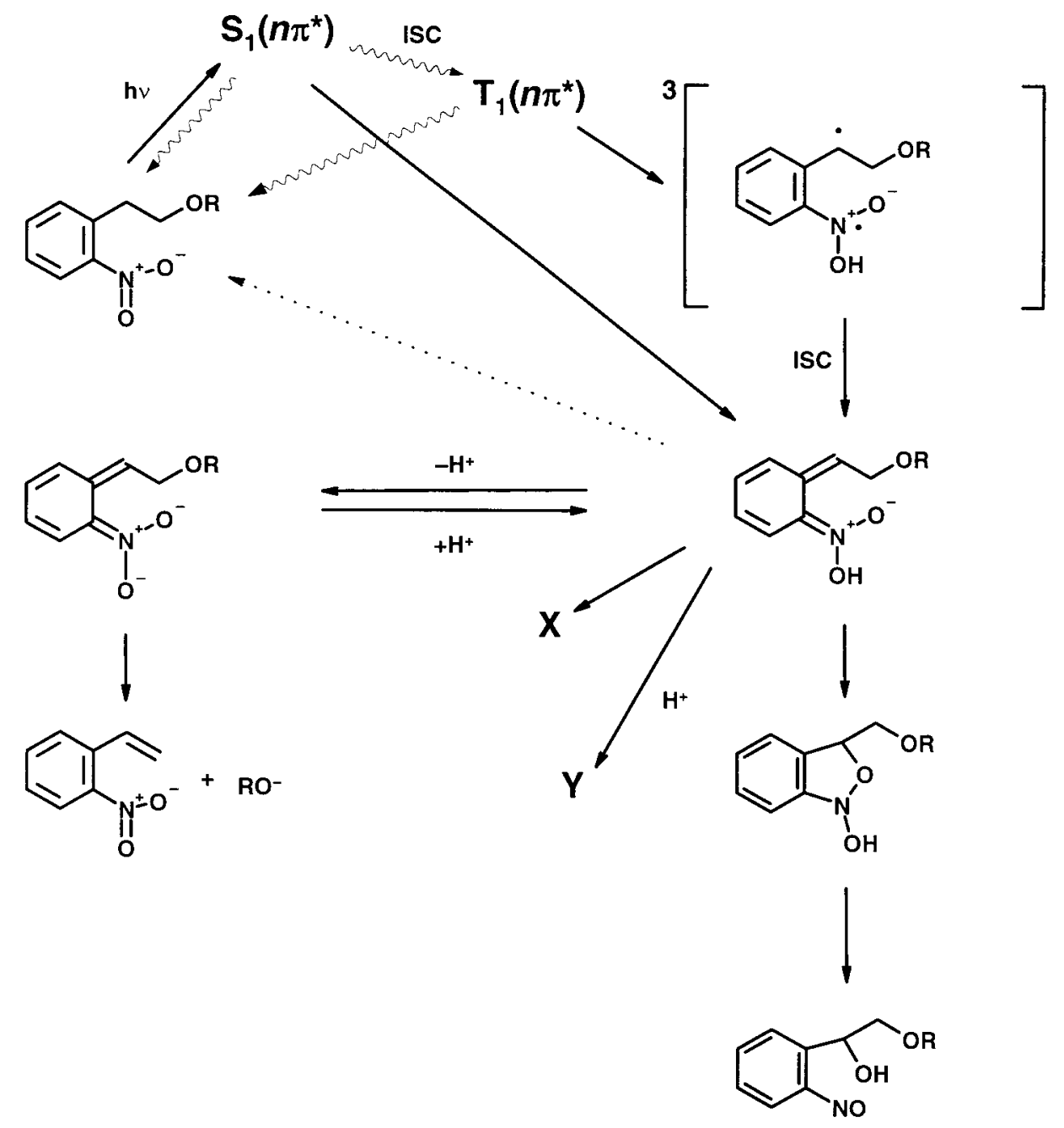

observed, which is unequivocal evidence of the reversibility of the protolytic process. For compound 3, e.g. (cf. Fig. 3), in $\mathrm{MeCN} / \mathrm{H}_{2} \mathrm{O} 1: 1$, we estimate the following rate parameters: $2 \cdot 10^{6} \mathrm{~s}^{-1}$ for the rate constant of protolytic dissociation and $2 \cdot 10^{10} \mathrm{M}^{-1} \mathrm{~s}^{-1}$, i.e. close to diffusion-controlled, for the rate constant of protonation by $\mathrm{H}_{3} \mathrm{O}^{+}$. These rate constants correspond to a $\mathrm{p} K_{\mathrm{a}}$ of 4 which is similar to what has been published for other $o$-quinonoid $a c i$-nitro compounds [16].

From the correlation of the final product distribution with the position of the protolytic dissociation equilibrium, we conclude that the aci-nitro anion is the starting point for the $\beta$-elimination pathway, whereas the undissociated aci-nitro compound gives rise to formation of the nitroso product. The connection between $\beta$-elimination and the aci-nitro anion is in fact what would have been reasonably anticipated. It is well- 
known that in the presence of strong bases, $\beta$-elimination from $o$ NPE compounds can be achieved in thermal reactions [17]. The photochemical way represented in the Scheme just reduces the required basicity of the proton acceptor. Under photochemical conditions, even the basicity of $\mathrm{H}_{2} \mathrm{O}$ is sufficient. It must be borne in mind, however, that, even if $\beta$-elimination can be supported by shifting the protolytic equilibrium from the aci-nitro compound to the anion, since the latter process is reversible, the yield into the $\beta$-elimination channel is ultimately determined by the kinetics of the elimination step itself. The rate of this process is expected to depend on the properties of the leaving group. For example, the rate should decrease in the series $\mathrm{ROC}(\mathrm{O}) \mathrm{O}^{-}, \mathrm{RCOO}^{-}, \mathrm{HO}^{-}$. So far, we did not attempt to quantify the difference between the former two of them, but $\mathrm{HO}^{-}$is clearly so slow that in this case, $\beta$-elimination cannot compete with the nitroso channel.

The reaction path to the nitroso product is usually assumed to involve a cyclic intermediate [8] that mediates the transfer of an O-atom from the nitro group to the exocyclic $\mathrm{C}(\alpha)$. We assume that the same happens in case of the $o$ NPE compounds. However, in contrast to the $o \mathrm{NB}$ case, where the protected moiety is released from the exocyclic $\mathrm{C}(\alpha)$ center after the O-transfer, in the $o$ NPE case, the reaction stops at this point, because the protected moiety is attached to the $\beta$-position and, therefore, not affected by the O-transfer. For $o$ NPE compounds to be used as photolabile protecting groups, it is, therefore, important to avoid the nitroso reaction path. Nevertheless, our mechanistic findings regarding the nitroso pathway with the $o$ NPE compounds can be applied to the $o \mathrm{NB}$ case too, and they contribute valuable details for a more general insight into the reaction mechanism of the nitroso-product formation. In particular, our results provide firm evidence that, contrary to the general notion, the ring closure reaction on the way to the nitroso product involves the undissociated aci-nitro form rather than its anion. This finding confirms a prediction recently published by Schaper et al. [18] on the basis of semi-empirical (AM1) quantum-chemical calculations. So far, no direct spectroscopic evidence of the cyclic intermediate has been reported. We, too, did not see a spectroscopic transient in the UV/VIS that could be assigned to it, but we were able to detect the appearance of the nitroso compound, which occurs in about a second ( $c f$. Fig. 2, b for compound 2). Therefore, it seems reasonable to assign this value to the lifetime of the cyclic dihydroisoxazol intermediate.

Finally, we address the two unidentified products $\mathrm{X}$ and $\mathrm{Y}$. Since their formation is found under conditions where the undissociated aci-nitro compound prevails, the latter species may function as their precursor. However, further investigations are needed to clarify their structure and mechanisms of formation.

\section{Experimental Part}

General. TLC: precoated silica-gel thin layer sheets 60 F254 from Merck. Prep. column chromatography (CC): silica gel $0.04 \mathrm{~mm}$ from Baker. UV/VIS: Perkin-Elmer Lambda-15; $\lambda_{\max }$ in $\mathrm{nm}(\lg \varepsilon) .{ }^{1} \mathrm{H}-\mathrm{NMR}$ (unless otherwise noted): Bruker $A C-250 ; \delta$ in ppm rel. to $\mathrm{SiMe}_{4}$.

1. 2-(2-Chloro-6-nitrophenyl)ethyl Acetate (1). A mixture of 2-(2-chloro-6-nitrophenyl)ethanol [19] (0.53 g, $2.5 \mathrm{mmol})$ and $\mathrm{Ac}_{2} \mathrm{O}(3 \mathrm{ml})$ in pyridine $(3 \mathrm{ml})$ was stirred at r.t. for $4 \mathrm{~h}$. After evaporation, the residue was coevaporated with $\mathrm{MeOH}(3 \times 5 \mathrm{ml})$ and toluene $(2 \times 5 \mathrm{ml})$, dissolved in $\mathrm{CHCl}_{3}(30 \mathrm{ml})$, and treated with sat. $\mathrm{NaHCO}_{3}$ soln. $(30 \mathrm{ml})$. The org. phase was dried $\left(\mathrm{Na}_{2} \mathrm{SO}_{4}\right)$ and evaporated and the residue purified by $\mathrm{CC}$ (silica gel, $\left.10 \times 2.5 \mathrm{~cm}, \mathrm{CH}_{2} \mathrm{Cl}_{2}\right): 0.62 \mathrm{~g}(97 \%)$ of 1 . Colorless oil. ${ }^{1} \mathrm{H}-\mathrm{NMR}\left(\mathrm{CDCl}_{3}\right): 7.73-7.26(\mathrm{~m}, 3$ arom. $\mathrm{H})$; $4.33\left(t, \mathrm{PhCH}_{2} \mathrm{CH}_{2} \mathrm{O}\right) ; 3.39\left(m, \mathrm{PhCH}_{2} \mathrm{CH}_{2} \mathrm{O}\right) ; 2.02(s, \mathrm{Ac})$. 
2. 2-(2-Nitrophenyl)propyl Acetate (2). As described for 1, with 2-(2-nitrophenyl)propan-1-ol [20] (7;1.0 g, $5.5 \mathrm{mmol}), \mathrm{Ac}_{2} \mathrm{O}(10 \mathrm{ml})$, and pyridine $(10 \mathrm{ml})$. Workup with $\mathrm{MeOH}(3 \times 10 \mathrm{ml})$, toluene $(2 \times 10 \mathrm{ml}), \mathrm{CHCl}_{3}$ $(50 \mathrm{ml})$, sat. $\mathrm{NaHCO}_{3}$ soln. $(50 \mathrm{ml})$, and $\mathrm{CC}$ as described gave $1.2 \mathrm{~g}(97 \%)$ of 2. Colorless oil. ${ }^{1} \mathrm{H}-\mathrm{NMR}$ $\left(\mathrm{CDCl}_{3}\right): 7.75\left(d, 1 \mathrm{H}\right.$ o to $\left.\mathrm{NO}_{2}\right) ; 7.50(m, 3$ arom. $\mathrm{H}) ; 4.21\left(m, \mathrm{CHCH}_{2} \mathrm{O}\right) ; 3.72\left(m, \mathrm{MeCHCH}_{2} \mathrm{O}\right) ; 1.99(s, \mathrm{Ac})$; $1.36\left(d, \mathrm{MeCHCH}_{2} \mathrm{O}\right)$.

3. 3-Ethyl-4-nitrobenzenamine [21]. $N$-(3-Ethylphenyl)acetamide [21] (33 g, $0.2 \mathrm{~mol})$ was slowly added under intense mechanical stirring to $100 \mathrm{ml}$ of conc. sulfuric acid. To the resulting soln., cooled to $-15^{\circ}$, fumic nitric acid $(9.5 \mathrm{~g}, 6.2 \mathrm{ml}, 0.15 \mathrm{~mol})$ was added dropwise, while keeping the temp. below $-10^{\circ}$. After $75 \mathrm{~min}$ at -20 to $-10^{\circ}$, the soln. was poured on ice, neutralized with solid $\mathrm{Na}_{2} \mathrm{CO}_{3}$, and extracted with $\mathrm{Et}_{2} \mathrm{O}(3 \times 250 \mathrm{ml})$. The org. phase was washed with $\mathrm{H}_{2} \mathrm{O}(600 \mathrm{ml})$, dried $\left(\mathrm{Na}_{2} \mathrm{SO}_{4}\right)$, and evaporated. The crude dark yellow oil $(39 \mathrm{~g})$ was heated in the presence of conc. $\mathrm{HCl}$ soln. $(125 \mathrm{ml})$ under reflux for $2.5 \mathrm{~h}$. After cooling, the precipitate was washed with $\mathrm{H}_{2} \mathrm{O}$, suspended in $1 \mathrm{M} \mathrm{NaOH}(300 \mathrm{ml})$, and extracted with $\mathrm{Et}_{2} \mathrm{O}(2 \times 150 \mathrm{ml})$. The org. phase was dried $\left(\mathrm{Na}_{2} \mathrm{SO}_{4}\right)$ and evaporated to give again a brown solid $(14.2 \mathrm{~g})$. The combined filtrates and the $\mathrm{NaOH}$ phase were neutralized and again extracted with $\mathrm{Et}_{2} \mathrm{O}$. The org. phase yielded, after drying $\left(\mathrm{Na}_{2} \mathrm{SO}_{4}\right)$ and evaporation, $16 \mathrm{~g}$ of a dark oil. The crude product was purified by CC (each oily fraction separately, with silica gel $(235 \mathrm{~g}), 7 \times 14 \mathrm{~cm}$, petroleum ether/AcOEt $20: 1 \rightarrow 2: 1): 18.09 \mathrm{~g}(54 \%)$ of amine. Yellow solid. M.p. $84-85^{\circ}$ ([21]: $\left.80-81^{\circ}\right)$; UV (MeOH): 203 (4.21), 231 (3.82), 245 (sh, 3.69), 372 (sh, 4.09). ${ }^{1} \mathrm{H}-\mathrm{NMR}\left(\mathrm{CDCl}_{3}\right)$ : $7.96(m, \mathrm{H}-\mathrm{C}(5)) ; 6.47(m, \mathrm{H}-\mathrm{C}(2), \mathrm{H}-\mathrm{C}(6)) ; 4.23$ (br. $\left.s, \mathrm{NH}_{2}\right) ; 2.93\left(q, \mathrm{MeCH}_{2}\right) ; 1.24\left(t, \mathrm{MeCH}_{2}\right) .{ }^{13} \mathrm{C}-\mathrm{NMR}$ $\left(600 \mathrm{MHz}, \mathrm{CDCl}_{3}\right): 151.30(\mathrm{C}(1)) ; 143.25(\mathrm{C}(3)) ; 139.42$ (C(4)); $128.35(\mathrm{C}(5)) ; 115.35$ (C(2)); $111.72(\mathrm{C}(2))$; $27.48\left(\mathrm{MeCH}_{2}\right) ; 14.67\left(\mathrm{MeCH}_{2}\right)$.

4. 5-Bromo-1-ethyl-2-nitrobenzene. Finely powdered 3-ethyl-4-nitrobenzenamine (16.6 g, $0.1 \mathrm{~mol})$ was added to a warm $\left(60^{\circ}\right)$ mixture of $48 \% \mathrm{HBr}$ soln. $(95 \mathrm{ml})$ and $\mathrm{H}_{2} \mathrm{O}(155 \mathrm{ml})$. The resulting soln. was cooled rapidly to $0^{\circ}$, and the resulting suspension was diazotized at $0-3^{\circ}$ with $\mathrm{NaNO}_{2}(7.0 \mathrm{~g}, 0.101 \mathrm{~mol})$ in $\mathrm{H}_{2} \mathrm{O}(20 \mathrm{ml})$. After stirring for $5 \mathrm{~min}$ at $0^{\circ}$, the soln. was treated with urea $(1 \mathrm{~g})$ and the mixture stirred for another $10 \mathrm{~min}$ and filtered off. The filtrate was added at r.t. to a stirred suspension of copper sulfate pentahydrate $(15 \mathrm{~g}, 60 \mathrm{mmol})$ and copper $(6 \mathrm{~g}, 94 \mathrm{mmol})$ in $\mathrm{HBr}(63 \mathrm{ml})$ and $\mathrm{H}_{2} \mathrm{O}(37 \mathrm{ml})$. The mixture was heated to $75^{\circ}$ for $1 \mathrm{~h}$ and, after cooling, extracted with AcOEt. The org. phase was washed with $1 \mathrm{M} \mathrm{NaOH}(150 \mathrm{ml})$ and $\mathrm{H}_{2} \mathrm{O}(200 \mathrm{ml})$, dried $\left(\mathrm{Na}_{2} \mathrm{SO}_{4}\right)$, and evaporated: $18.3 \mathrm{~g}(80 \%)$ of the bromo derivative. Yellow oil. B.p. $75-103^{\circ} / 0.005 \mathrm{mbar}$. UV (MeOH): 203 (4.19), 217 (sh, 3.98), 267 (3.91), 320 (sh, 3.21). ${ }^{1} \mathrm{H}-\mathrm{NMR}\left(250 \mathrm{MHz}, \mathrm{CDCl}_{3}\right): 7.76$ (d, $\left.\mathrm{H}-\mathrm{C}(3)\right)$; $7.50(d, \mathrm{H}-\mathrm{C}(6)) ; 7.45(d d, \mathrm{H}-\mathrm{C}(4)) ; 2.89\left(q, \mathrm{MeCH}_{2}\right) ; 1.27\left(t, \mathrm{MeCH}_{2}\right)$. Anal. calc. for $\mathrm{C}_{8} \mathrm{H}_{8} \mathrm{BrNO}_{2}(230.07)$ : C 41.77, H 3.50, N 6.09; found: C 41.71, H 3.59, N 6.08.

5. 2-(5-Bromo-2-nitrophenyl)propan-1-ol. A mixture of 5-bromo-1-ethyl-2-nitrobenzene $(1.39 \mathrm{~g}, 6 \mathrm{mmol})$ and paraformaldehyde $(210 \mathrm{mg}, 7 \mathrm{mmol})$ in dry DMSO $(10 \mathrm{ml})$ was treated with $\mathrm{KO}^{\prime} \mathrm{Bu}(100 \mathrm{mg}, 0.89 \mathrm{mmol})$ in ${ }^{t} \mathrm{BuOH}(4 \mathrm{ml})$. After stirring for $15 \mathrm{~min}$ at r.t. and $2 \mathrm{~h}$ at $80^{\circ}$, the mixture was neutralized, diluted with sat. $\mathrm{NaCl}$ soln. $(25 \mathrm{ml})$, and extracted with AcOEt. The org. phase was dried $\left(\mathrm{Na}_{2} \mathrm{SO}_{4}\right)$ and evaporated and the crude product purified by CC (silica gel, $(45 \mathrm{~g}), 4 \times 12 \mathrm{~cm}$, toluene $\rightarrow$ toluene/AcOEt $8: 1): 1.32 \mathrm{~g}(85 \%)$ of a yellow oil. UV (MeOH): 202 (4.16), 218 (sh, 3.95), 263 (3.76), 330 (sh, 2.96). ${ }^{1} \mathrm{H}-\mathrm{NMR}\left(\mathrm{CDCl}_{3}\right): 7.63$ ( $m, \mathrm{H}-\mathrm{C}(3)$, $\mathrm{H}-\mathrm{C}(6)) ; 7.47(d d, \mathrm{H}-\mathrm{C}(4)) ; 4.74\left(m, \mathrm{MeCHCH}_{2} \mathrm{OH}\right) ; 3.52$ (sext., $\left.\mathrm{MeCHCH}_{2} \mathrm{OH}\right) ; 1.68$ (br. $\left.s, \mathrm{OH}\right) ; 1.30$ (d, $\left.\mathrm{Me} \mathrm{CHCH}_{2} \mathrm{OH}\right)$. Anal. calc. for $\mathrm{C}_{9} \mathrm{H}_{10} \mathrm{BrNO}_{3}$ (260.09): C 41.56, H 3.88, N 5.39; found: C 41.74, H 3.95, N 5.27.

6. 2-(5-Bromo-2-nitrophenyl)propyl Carbonochloridate. To a cold soln. $\left(0^{\circ}\right)$ of diphosgene (=trichloromethyl carbonochloridate; $740 \mathrm{mg}, 455 \mu \mathrm{l}, 3.8 \mathrm{mmol}$ ) in dry THF $(4 \mathrm{ml})$, 2-(5-bromo-2-nitrophenyl)propan-1-ol $(650 \mathrm{mg}, 2.5 \mathrm{mmol})$ and $\mathrm{Et}_{3} \mathrm{~N}(255 \mathrm{mg}, 350 \mu \mathrm{l}, 2.5 \mathrm{mmol})$ in dry THF $(4 \mathrm{ml})$ were added. After stirring for $1 \mathrm{~h}$ at $0^{\circ}$, the solvent was evaporated: $805 \mathrm{mg}(99 \%)$ of the carbonochloridate. Yellow oil. ${ }^{1} \mathrm{H}-\mathrm{NMR}\left(\mathrm{CDCl}_{3}\right): 7.72(d, \mathrm{H}-\mathrm{C}(3)) ; 7.55(m, 2 \mathrm{H}, \mathrm{H}-\mathrm{C}(6), \mathrm{H}-\mathrm{C}(4)) ; 4.45\left(m, \mathrm{MeCHCH}_{2} \mathrm{O}\right) ; 3.80$ (sext. $\left.\mathrm{MeCHCH}_{2} \mathrm{O}\right) ; 1.39\left(d, \mathrm{MeCHCH}_{2} \mathrm{O}\right)$.

7. 2-(5-Bromo-2-nitrophenyl)propyl Methyl Carbonate (3). To a cold soln. of $\mathrm{MeOH}(20 \mathrm{ml})$ and $\mathrm{Et}_{3} \mathrm{~N}$ ( $2 \mathrm{ml})$, 2-(5-bromo-2-nitrophenyl)propyl carbonochloridate $(1.5 \mathrm{~g}, 4.7 \mathrm{mmol})$ was added dropwise at $0-5^{\circ}$. After stirring for $45 \mathrm{~min}$ at r.t., the solvent was evaporated and the residue purified by CC (silica gel $(60 \mathrm{~g})$, $\left.3.5 \times 16 \mathrm{~cm}, \mathrm{CH}_{2} \mathrm{Cl}_{2}\right): 1.39 \mathrm{~g}(93 \%)$ of 3 . Yellow oil. ${ }^{1} \mathrm{H}-\mathrm{NMR}\left(\mathrm{CDCl}_{3}\right): 7.66(d, \mathrm{H}-\mathrm{C}(3)) ; 7.58(d, \mathrm{H}-\mathrm{C}(6))$; $7.49(d d, \mathrm{H}-\mathrm{C}(4)) ; 4.27\left(m, \mathrm{MeCHCH}_{2} \mathrm{O}\right) ; 3.73\left(m, \mathrm{MeCHCH}_{2} \mathrm{O}, \mathrm{MeO}\right) ; 1.34\left(d, \mathrm{MeCHCH}_{2} \mathrm{O}\right)$.

8. Methyl 2-(2-Nitrophenyl)propyl Carbonate (6). To a cold soln. of $\mathrm{MeOH}(20 \mathrm{ml})$ and $\mathrm{Et}_{3} \mathrm{~N}(2 \mathrm{ml})$, 2-(2nitrophenyl)propyl carbonochloridate [10] $(1.5 \mathrm{~g}, 6.1 \mathrm{mmol})$ in $\mathrm{CH}_{2} \mathrm{Cl}_{2}(5 \mathrm{ml})$ was added at $0-4^{\circ}$. After stirring for $1 \mathrm{~h}$, the mixture was evaporated and the residue purified by CC (silica gel, $\left.10 \times 2.5 \mathrm{~cm}, \mathrm{CHCl}_{3}\right): 1.35 \mathrm{~g}(92 \%)$ of 6. Colorless oil. ${ }^{1} \mathrm{H}-\mathrm{NMR}\left(\left(\mathrm{D}_{6}\right) \mathrm{DMSO}\right): 7.82\left(d, 1 \mathrm{H} o\right.$ to $\left.\mathrm{NO}_{2}\right) ; 7.68-7.47$ ( $m, 3$ arom. $\left.\mathrm{H}\right) ; 4.26$ $\left(m, \mathrm{MeCHCH}_{2} \mathrm{O}\right) ; 3.63(s, \mathrm{MeO}) ; 3.47\left(m, \mathrm{MeCHCH}_{2} \mathrm{O}\right) ; 1.26\left(d, \mathrm{MeCHCH}_{2} \mathrm{O}\right)$. 
9. Photochemical Synthesis of 2-(2-Nitrosophenyl)propan-1,2-diol (8). 2-(2-Nitrophenyl)propan-1-ol (7; $548 \mathrm{mg}, 3 \mathrm{mmol}$ ) was dissolved in $\mathrm{MeCN} / \mathrm{H}_{2} \mathrm{O} 1: 1$ (300 ml) and irradiated for $70 \mathrm{~min}$ at r.t. in a photochemical reaction vessel equipped with a 150-W high-pressure $\mathrm{Hg}$ lamp. Throughout the reaction, the lamp was cooled, and the soln. was purged with $\mathrm{N}_{2}$ (TLC and UV/VIS monitoring). The solvent was evaporated and the residue purified by CC (silica gel $(18 \mathrm{~g}), 2 \times 15 \mathrm{~cm}$, petroleum ether/AcOEt $8: 1)$ : 8. Greenish oil. ${ }^{1} \mathrm{H}-\mathrm{NMR}(400 \mathrm{MHz}$, $\left.\mathrm{CD}_{3} \mathrm{CN}\right): 8.07(d, \mathrm{H}-\mathrm{C}(3)) ; 7.76(t, \mathrm{H}-\mathrm{C}(5)) ; 7.27(t, \mathrm{H}-\mathrm{C}(4)) ; 6.08(d, \mathrm{H}-\mathrm{C}(6)) ; 4.03\left(m, \mathrm{MeCCH}_{2}\right) ; 1.85$ $(s, \mathrm{MeCCH})$.

10. Direct Photolysis of 7 in an NMR Tube. In an NMR tube, $7(50 \mathrm{mg}, 0.3 \mathrm{mmol})$ was dissolved in $\mathrm{CD}_{3} \mathrm{CN}$ $(0.6 \mathrm{ml})$ and $\mathrm{D}_{2} \mathrm{O}(0.6 \mathrm{ml})$. The tube was irradiated by a cooled 150 -W high-pressure Hg lamp. ${ }^{1} \mathrm{H}-\mathrm{NMR}$ Spectra, taken before irradiation and after 23, 50, and $75 \mathrm{~min}$, showed the formation of the photoproduct 8 as characterized above. After 75 min of irradiation, the ${ }^{1} \mathrm{H}$-NMR showed further secondary photoproducts or byproducts which were not characterized.

11. Time-Resolved Experiments. Nanosecond laser-flash-photolysis experiments were carried out on the laser system described in [22], however, with a Nd-YAG laser (Spectra Physics, Quanta Ray GCR, 150-5) operated at its third harmonics $(355 \mathrm{~nm})$ replacing the excimer laser. The laser pulse width was $5-7 \mathrm{~ns}$. The pulse energy was adjusted to $c a .20 \mathrm{~mJ}$ over a cross section of about $25 \mathrm{~mm}^{2}$. The laser was run at a repetition rate of $1 \mathrm{~Hz}$ and the transient signals, recorded in the kinetic mode at fixed wavelength, were averaged over typically 4 pulses. The sample solution was contained in a cylindrical flow cell (5-mm cross section, 10-mm path length) and the flow rate between laser shots adjusted such that the soln. was replaced between any two laser shots. Details of the laser flash apparatus can be found in [23].

12. Continuous Illumination. For the determination of quantum yields by continuous illumination, a $200-\mathrm{W}$ $H B O$ lamp combined with a heat filter (5-cm optical pathlength filled with $0.3 \mathrm{M} \mathrm{CuSO}_{4}$ in $\mathrm{H}_{2} \mathrm{O}$ ) was used. The 366-nm Hg line was selected by a Schott interference filter. The light intensity was measured by chemical actinometry by means of the azobenzene method [24]. Standard 10-mm-pathlength stoppered quartz cuvettes were used. Some quantum yields were determined by irradiation with the pulsed Nd-YAG laser ( $355 \mathrm{~nm})$. In these cases, the laser was run at low energy $(5 \mathrm{~mJ})$, and the absorbed dose of radiation was measured by an energy meter (Laser precision RK 3230). HPLC: Merck-Hitachi-7000 equipment with interface, autosampler, pump, and diode array detector; column Lichrosorb RP-18, linear gradient of $\mathrm{MeCN}$ in $\mathrm{H}_{2} \mathrm{O}$.

Quantum yields were calculated by Eqn. 1, where the index $i$ represents the starting material in case of $\phi_{\text {tot }}$ or the released caged compound in case of $\phi_{\text {rel }}$. The concentration change $\Delta c_{i}$ during the time interval $\Delta t$ was determined by HPLC. The quantities $A, \varepsilon_{1}$, and $d$ denote the total absorbance at the irradiation wavelength in the middle of the considered time interval of irradiation, the molar absorption coefficient of the starting compound at the irradiation wavelength, and the optical path length of the cell, respectively; $c_{1}$ is the concentration of the starting compound in the middle of the considered time interval of irradiation.

$$
\Phi_{i}=\frac{\left|\Delta c_{i}\right|}{\Delta t I\left(1-10^{-A}\right) \frac{\varepsilon_{1} c_{1} d}{A}}
$$

The quantity $c_{1}$ was obtained from the HPLC experiment by comparing the peak area of the caged substrate of an irradiated sample at the wavelength of its maximum absorption with an unirradiated one. In experiments where thymidine recovery was determined, an aliquot of a thymidine soln. of the same concentration as the caged substrate was used as a reference. In a typical experiment, $6-8$ aliquots of $0.5 \mathrm{~mm}$ solns. were irradiated for different periods to a maximum extent of $50 \%$ loss of starting material. Aliquots of 10 or $20 \mu$ l were analysed as described above, and the resulting quantum yields were averaged.

We thank Prof. Dr. Evgeny Kvasyuk and Dr. Sigrid Bühler for the supply of various 2-(2-nitrophenyl)ethanol derivatives and Karsten Obert for the synthesis and characterization of 2-(2-nitrosophenyl)propane-1,2-diol.

\section{REFERENCES}

[1] V. N. R. Pillai, Synthesis 1980, 1; V. N. R. Pillai, in 'Organic Photochemistry', Ed. A. Padwa, Marcel Dekker, New York and Basel, 1987, Vol. 9, p. 225.

[2] J. E. T. Corrie, D. R. Trentham, in 'Bioorganic Photochemistry Series', Ed. H. Morrison, WileyInterscience, 1993, Vol. 2, p. 243. 
[3] S. P. A. Fodor, J. L. Read, M. C. Pirrung, L. Stryer, A. T. Lu, D. Solas, Science (Washington D. C.) 1991, 251, 767.

[4] G. H. McGall, A. D. Barone, M. Diggelmann, S. P. A. Fodor, E. Gentalen, N. Ngo, J. Am. Chem. Soc. 1997, 119, 5081.

[5] R. J. Lipshutz, S. P. A. Fodor, T. R. Gingeras, D. J. Lockhart, Nat. Gen. Suppl. 1999, 21, 20.

[6] W. G. Bains, C. Smith, J. Theor. Biol. 1988, 135, 303; A. C. Pease, D. Solas, E. J. Sullivan, M. T. Cronin, C. P. Holmes, S. P. A. Fodor, Proc. Natl. Acad. Sci. U.S.A. 1994, 91, 5022.

[7] G. Ciamician, P. Silber, Chem. Ber. 1901, 34, 2040.

[8] J. A. McCray, D. R. Trentham, Annu. Rev. Biophys. Chem. 1989, 18, 239.

[9] H. Morrison, B. H. Migdalof, J. Org. Chem. 1965, 30, 3996.

[10] A. Hasan, K.-P. Stengele, H. Giegrich, P. Cornwell, K. R. Isham, R. A. Sachleben, W. Pfleiderer, R. S. Foote, Tetrahedron 1997, 53, 4247.

[11] H. Giegrich, S. Eisele-Bühler, Chr. Hermann, E. Kvasyuk, R. Charubala, W. Pfleiderer, Nucleosides/ Nucleotides 1998, 17, 1987.

[12] G. Wettermark, J. Phys. Chem. 1962, 66, 2560.

[13] R. W. Yip, D. K. Sharma, R. Giasson, D. Gravel, J. Phys. Chem. 1985, 89, 5328; R. W. Yip, D. K. Sharma, Res. Chem. Intermed. 1989, 11, 109.

[14] S. Walbert, U. E. Steiner, to be published.

[15] Q. Q. Zhu, W. Schnabel, H. Schupp, J. Photochem. 1987, 39, 317.

[16] G. Wettermark, E. Black, L. Dogliotti, Photochem. Photobiol. 1965, 4, 229.

[17] E. Uhlmann, W. Pfleiderer, Helv. Chim. Acta 1981, 64, 1688; S. Alunni, R. Ruzziconi, O. Teofrasti, Res. Chem. Intermed. 1999, 25, 483.

[18] K. Schaper, D. Dommaschke, S. Globisch, S. A. Madani-Mobarekeh, J. Inf. Recording 2000, 25, 339.

[19] Y. Tsuji, S. Kotachi, K.-T. Huh, J. Org. Chem. 1990, 55, 580.

[20] S. Torii, Y. Murakami, H. Tanaka, K. Okamoto, J. Org. Chem. 1986, 31, 3143.

[21] H. Wieland, L. Horner, Liebigs Ann. 1938, 536, 89.

[22] T. Ulrich, U. E. Steiner, W. Schlenker, Tetrahedron 1986, 42, 6131.

[23] M. Linsenmann, Doctoral Dissertation, University of Konstanz, 1997.

[24] G. Gauglitz, S. Hubig, J. Photochem. 1981, 15, 255; G. Gauglitz, ibid. 1976, 5, 41. 